\title{
THE SOCIAL COMPOSITION OF THE NAZI PARTY IN EUTIN, 1925-32*
}

The supporters of the Nazi party prior to 1933 can be divided into two groups. Much the larger of these were the millions of voters who, beginning in the summer of 1930, cast their ballots for Hitler and his party. The second group, whose adherence to the Nazi movement included but also went beyond voting for its candidates in elections, were the formal members of the NSDAP. Between February 1930 and May 1932, they increased in number from approximately $170-180,000$ to some $850-900,000 .^{1}$

Who were the members of the NSDAP? The following essay is part of a wider study in preparation on the social and political history of the town of Eutin in Holstein between the world wars. By examining in detail the membership of a single Ortsgruppe (local unit), that of Eutin, it suggests one means of utilizing the almost unmanageable weight of documentation upon which any analysis of the composition of the Nazi party must rest: the

\footnotetext{
* I am indebted to the Canada Council for fellowship grants during 1973-76 to conduct research on Eutin between 1918 and 1939.

'Führer befiehl. . Selbstzeugnisse aus der "Kampfzeit" der NSDAP. Dokumentation und Analyse, ed. by Albrecht Tyrell (Düsseldorf, 1969), p. 352; and Ausgewählte Dokumente zur Geschichte des Nationalsozialismus 1933-1945, ed. by Hans-Adolf Jacobsen and Werner Jochmann (Bielefeld, 1961ff.). The official figures quoted in these sources have been reduced $10-15 \%$ to reflect the degree of fluctuation in party membership Tyrell believes took place; this assumption is examined in ch. VI below. See also Mein Kampf (Boston, 1943), II, ch. 11, for Hitler's distinction between "passive" supporters, or voters, and "active" members of the Nazi movement: "Being a supporter is rooted only in understanding, membership in the courage personally to advocate and disseminate what has been understood. Understanding in its passive form corresponds to the majority of mankind which is lazy and cowardly. Membership requires an activistic frame of mind and thus corresponds only to the minority of men."
} 
more than $10,700,000$ cards comprising the NSDAP Zentralkartei (ZK, master file), together with extensive supplementary materials, housed in the Berlin Document Center (BDC). ${ }^{2}$ Of course, the problematical nature of all such "case-studies" is obvious: the specific example chosen must be representative of the overall phenomenon under discussion. The appositeness of any particular case can only be demonstrated, however, after a sufficient number of examples have been studied in turn to show whether each is, or is not, typical of the general problem. ${ }^{3}$ In order to break out of this logical circle, I have selected one Nazi Ortsgruppe for examination.

The choice of Eutin was far from random. The town, with a population of 7,202 in May 1932 and situated on the railway line linking the cities of Lübeck ( 35 kilometers to the southeast) and Kiel (50 kilometers to the northwest) amid the lakes and farms of Eastern Holstein, was widely recognized as a Hochburg der Bewegung (Nazi stronghold) before 1933. ${ }^{4}$ Although the NSDAP received only 151 of the more than 3,600 ballots cast in Eutin during the Reichstag election of May 1928, the outcome in September 1930, when it increased its support almost eleven-fold to 1,637

2 George C. Browder, "Problems and Potentials of the Berlin Document Center". in: Central European History, V (1972), pp. 362-80. Another approach, employing computer techniques, has been suggestively applied by Michael $\mathrm{H}$. Kater in a series of articles beginning with "Zur Soziographie der frühen NSDAP", in: Vierteljahrshefte für Zeitgeschichte, XIX (1971), pp. 124-59, and most recently "Sozialer Wandel in der NSDAP im Zuge der nationalsozialistischen Machtergreifung", in: Faschismus als soziale Bewegung, ed. by Wolfgang Schieder (Hamburg, 1976), pp. 25-67. Jürgen Genuneit of Hamburg University is also completing a computer-based dissertation on the socio-economic structure of the early NSDAP. I owe several suggestions for the present paper to correspondence and conversations with both these scholars.

${ }^{3}$ Geoffrey Pridham, Hitler's Rise to Power: The Nazi Movement in Bavaria 1923-1933 (London, 1973), p. 1. The pioneer study of the Nazi movement at the local level by William S. Allen, The Nazi Seizure of Power: The Experience of a Single German Town 1930-1935 (Chicago, 1965), deals with the subject of party membership in "Thalburg" (that is, Northeim) too imprecisely. Thus his statement that the town itself "had only about forty actual members of the NSDAP prior to 1933" apparently is based solely upon the recollections of three non-Nazi citizens some thirty years later and, moreover, seems highly improbable in view of the "astounding" activity of the Northeim Ortsgruppe during that period which he records (ibid., pp. 72, 314, note 21). Elsewhere Allen asserts that "in January, 1933, there were fewer than a hundred dues-paying Nazis" in Northeim (ibid., p. 233), a figure no more exact or particularly credible.

4 Anzeiger für das Fürstentum Lübeck (hereafter AFL), Eutin, 4 May 1932; Denkschrift zur Eingliederung des oldenburgischen Landesteils Lübeck in die Provinz SchleswigHolstein am 1. April 1937, ed. by [Hermann] Diercks (Plön, 1937), p. 178; and Rudolf Heberle, Landbevölkerung und Nationalsozialismus. Eine soziologische Untersuchung der politischen Willensbildung in Schleswig-Holstein 1918-1932 (Stuttgart, 1963), p. 42. 
votes, left it the town's strongest single political party. ${ }^{5}$ The town-council election two months later saw seven of the fifteen members returned Nazis where none had been previously. Following the Oldenburg Landtag election on 29 May 1932, which gave the NSDAP its first majority in a German state parliament, ${ }^{6}$ the local Nazi leader Johann Heinrich Böhmcker became head of the government in the town ${ }^{7}$ - fully six months before Hitler was appointed Chancellor of the Reich. Eutin was clearly among the successful targets of the special propaganda effort the party directed at small towns in predominantly rural areas such as SchleswigHolstein after $1928 .^{8}$ Its effectiveness was even more strikingly reflected in the growth of Nazi membership in Eutin.

Among the surviving records of the Eutin NSDAP is a membership list with the names of 469 individuals, for the most part including their addresses and occupations. Although undated, one name is crossed out and accompanied by the following notation: "ejected $27 /$ iv.32". 9 The list was evidently compiled, therefore, on the eve of the party's accession to power in Oldenburg. A search of the names through the principal indexes and collections of the BDC - the ZK, the Party Correspondence (PK), the SA,

5 The remaining parties polled the following totals in 1928: SPD 1,356; DNVP 1,042; DVP 424; DDP 337; Reich Party 153; Center 118; and KPD 27. Two years later, the DNVP dropped $76.6 \%$ to 244 votes, the Reich Party $62 \%$, the DDP/State Party $29 \%$, the DVP $26 \%$, and the SPD $8.4 \%$ to 1,242 votes. Other than the Nazis, only the Center and the KPD upped their vote (to 135 and 35 respectively), while the newly formed Conservative People's Party probably collected its 148 votes from among former supporters of the DNVP. Reichstagswahl am 20. Mai 1928, Stadtarchiv Eutin (hereafter SAE), No 585; and ibid., No 588, Reichstagswahl am 14. September 1930.

6 The returns in the town were: NSDAP 2,182 (55\% of the total vote); SPD 1,021 (25.8\%): DNVP 378 (9.5\%); KPD $122(3 \%)$; Center $115(2.9 \%)$; State Party $66(1.6 \%)$; and DVP/Economic Party 57 (1.4\%). AFL, 31 May 1932.

7 Although Eutin lay geographically within the Prussian province of Schleswig-Holstein, until April 1937 under a Regierungspräsident it was the administrative center of a substantially independent 540-square-kilometer enclave called "Landesteil Lübeck" belonging to the state of Oldenburg, whose capital was some 200 kilometers away to the southwest beyond the Weser River. For the political and constitutional history of this relic of eighteenth-century Kleinstaaterei, see Gustav Peters, Geschichte von Eutin (Neumünster, 1958); also Walther Schücking, Das Staatsrecht des Grossherzogtums Oldenburg (Tübingen, 1911), pp. 18ff.

${ }^{8}$ Führer befiehl, op. cit., pp. 150, 192-93, 224-25, 258; Gerhard Stoltenberg, Politische Strömungen im schleswig-holsteinischen Landvolk 1918-1933. Ein Beitrag zur politischen Meinungsbildung in der Weimarer Republik (Düsseldorf, 1962), pp. 143ff.; Dietrich Orlow, The History of the Nazi Party: 1919-1933 (Pittsburgh, 1969), pp. 117-18; and Charles P. Loomis and J. Allen Beegle, "The Spread of German Nazism in Rural Areas", in: American Sociological Review, XI (1946), pp. 724-34.

9 US National Archives (hereafter USNA), microfilm publications, microcopy T-81, roll 164, frames 302405-24. The original document is now deposited in the Landesarchiv Schleswig-Holstein (hereafter LASH), Acc. 52/1968. 
SS, Supreme Party Court, Reich Chamber of Culture, Nazi Teachers' League, and in the case of females the Nazi Women's Auxiliary records identified 416 or $88.7 \%$ as indisputably members of the NSDAP. (One woman, for whom a membership card was not found in the $Z K$, was nevertheless pictured in her PK file with a party badge in her lapel.) There are a number of reasons for concluding, however, that the 53 persons not traced in the BDC were Nazis as well.

For one thing, the ZK is generally thought to be only about $90 \%$ complete, ${ }^{10}$ which estimate compares favourably with the percentage of Eutin names located. Despite the conscientious efforts of the fersonnel at the BDC to achieve exactitude, the ZK almost certainly also contains an indeterminate number of simple filing errors. ${ }^{11}$ Furthermore, individuals who were either removed from the party for whatever reason or who died before 1945 are often not included in it. Even known Nazis, such as Eutin's mayor throughout the Third Reich, are sometimes missing. Women who married after joining had their membership cards refiled under their new surnames, which makes finding them extremely difficult; thus of the 65 females on the list, almost one-quarter could not be identified in the BDC, compared with only $9 \%$ of the men. Some early members of the party in Eutin were not properly registered at headquarters in Munich because of either malfeasance or incompetence on the part of local Nazi officials. Between 1926 and 1934, three successive treasurers of the Ortsgruppe "absconded with the [party] funds"; one of these "unscrupulous crooks" was presumably the individual crossed from the list and ejected on 27 April 1932. According to a member who joined in June 1929, the treasurer collected his dues but neither gave him a receipt nor stamped his membership book. As a result, his entry was never correctly validated and he had to reapply in 1937. In June 1935, several dozen Eutin Nazis appealed to Munich to reconfirm their membership: all had been reported "ejected", "quit", or "moved to an unknown address", according to the Gau treasurer of Schleswig-Holstein, "through the fault of the former treasurer of the Ortsgruppe". The same official also noted in February 1936 that "formerly there was no orderly conduct of business in the Eutin Ortsgruppe", as a result of which "the political leaders concerned without

${ }^{10}$ Cf. Browder, "Problems and Potentials", loc. cit., p. 366; letters from Professor Kater and Dr Tyrell to the author, 17 November and 4 December 1974; and Peter Merkl, Political Violence under the Swastika: 581 Early Nazis (Princeton, 1975), p. 636 and note 3.

11 Cf. Gaugeschäftsführer Gau Schleswig-Holstein der NSDAP to Ortsgruppe Eutin, 8 July 1931, USNA, T-81, roll 175, fr. 317799: "It is "understandable that national headquarters makes mistakes precisely in matters of filing." 
exception have since been removed from their offices". ${ }^{12}$ No less than six names listed could be identified in the PK only because of this circumstance; other "old fighters" probably chose not to petition because by the mid 1930's they had lost their original enthusiasm for the Nazi movement.

It appears justifiable to conclude, therefore, that all the persons listed were indeed early members of the NSDAP in Eutin, whatever may have transpired to exclude 53 of them from the records of the BDC. ${ }^{13}$ The analysis in the remainder of the paper is based on this assumption.

II

The categorization adopted in the German census of 16 June 1933 is generally followed to analyze the occupational structure of Eutin's Nazi party membership. However, the division by the census of the population socially according to occupational status ${ }^{14}$ has been expanded from six main and six subordinate to eleven main and nine subordinate categories in order to illustrate with greater accuracy the composition of the Ortsgruppe. For instance, whereas the 1933 census included all workers in a single category, Eutin's National Socialists who were workers are divided into two groups: the unskilled and those who had acquired some kind of special training. By utilizing such additional sources as the town's 1932 Adressbuch and the official voters' list for the September 1930 Reichstag election, an attempt is also made to establish whether each party member was economically dependent or independent - a valuable distinction in shaping an individual's social mentality and the political decisions deriving from it.

12 Cf. Gottfried Wolf to Kreisleitung Provinz Lübeck u. Ortsgruppenleitung Eutin der NSDAP, 15 June 1934, BDC/PK; also Gaugeschäftsführer Gau Schleswig-Holstein der NSDAP to Ortsgruppe Eutin, 9 and 30 January 1932, USNA, T-81, roll 164, frs 303265 and 303283. At least one treasurer apparently reported members to Munich as no longer belonging to the party while continuing to collect and pocket their dues!

13 As Table 5 indicates, four only formally joined the party after 1 May 1932. One, admitted on 1 August, may have had his application pending three months earlier. Two others, who entered on 1 May 1933 as members of nearby Ortsgruppen, had resided in Eutin a year before where they were already staunch supporters of Hitler's movement and were probably therefore listed. The remaining individual became a Nazi on 1 May 1937, the same day as did his brother, who first joined the NSDAP in 1929 but whose membership was later declared invalid; both may have been victims of a dishonest Eutin treasurer.

${ }^{14} \mathrm{Cf}$. Einführung in die Berufszählung. Systematische und alphabetische Verzeichnisse zur Berufszählung 1933, ed. by the Statistisches Reichsamt [Statistik des Deutschen Reichs, CDLIII, 1] (Berlin, 1936), pp. 16-20. 
Table 1: Composition of the Nazi Ortsgruppe in Eutin according to occupation (May 1932)

\begin{tabular}{|c|c|c|c|c|c|c|c|}
\hline \multirow[t]{2}{*}{ No } & \multirow{2}{*}{$\begin{array}{l}\text { Occupational } \\
\text { category }\end{array}$} & \multirow{2}{*}{\multicolumn{2}{|c|}{ Number Percent }} & \multicolumn{2}{|c|}{ Independent } & \multicolumn{2}{|c|}{ Dependent } \\
\hline & & & & No & $\%$ & No & $\%$ \\
\hline \multirow[t]{2}{*}{1} & professional, & & & & & & \\
\hline & managerial & 10 & 2.13 & 10 & 100 & - & _- \\
\hline \multirow{6}{*}{$\begin{array}{l}2 \\
3\end{array}$} & farmer & 6 & 1.28 & 6 & 100 & - & - \\
\hline & $\begin{array}{l}\text { merchant, store- } \\
\text { owner, }\end{array}$ & & & & & & \\
\hline & businessman & 75 & 15.99 & 53 & 70.67 & 22 & 29.33 \\
\hline & merchant & 37 & 7.89 & 15 & 40.54 & 22 & 59.46 \\
\hline & store-owner & 14 & 2.99 & 14 & 100 & - & - \\
\hline & businessman & 24 & 5.12 & 24 & 100 & - & - \\
\hline 4 & handicraftsman & 148 & 31.56 & 60 & 40.54 & 88 & 59.46 \\
\hline \multirow[t]{3}{*}{5} & employee & 81 & 17.27 & - & - & 81 & 100 \\
\hline & technical, foreman & 39 & 8.32 & - & - & 39 & 100 \\
\hline & shop, office & 42 & 8.96 & - & - & 42 & 100 \\
\hline \multirow[t]{3}{*}{6} & civil servant & 14 & 2.99 & - & - & 14 & 100 \\
\hline & leacher & 5 & 1.07 & - & - & 5 & 100 \\
\hline & other & 9 & 1.92 & - & - & 9 & 100 \\
\hline \multirow[t]{3}{*}{7} & worker & 68 & 14.50 & - & - & 68 & 100 \\
\hline & unskilled & 41 & 8.74 & - & - & $4 !$ & 100 \\
\hline & skilled & 27 & 5.76 & - & - & 27 & 100 \\
\hline 8 & domestic servant & 15 & 3.20 & - & - & 15 & 100 \\
\hline 9 & pupil, student & 9 & 1.92 & - & - & 9 & 100 \\
\hline 10 & pensioner & 2 & 0.43 & - & - & 2 & 100 \\
\hline 11 & unemployed woman & 41 & 8.74 & - & - & 41 & 100 \\
\hline
\end{tabular}

Although the occupational lists employed were compiled between September 1930 and May 1932, and the categories of occupations are adapted from the June 1933 census, no closer chronological concurrence among the available data was possible. The September 1930 list of voters is the latest preserved in the Eutin Town Archive before 1945. On the other hand, the last previous census undertaken in 1925 lies too far back to be used in assessing conditions in mid 1932; for one thing, 245 separate occupations were counted in 1933 but only 193 in $1925 .{ }^{15}$ Measured by the number of unemployed (6.2 million or $18.7 \%$ of the working population in February * 1932, 5.9 million and $18 \%$ in June 1933), ${ }^{16}$ the impact of Hitler's

15 Ibid., pp. 28ff.

16 Die Erwerbstätigkeit der Reichsbevölkerung, ed. by the Statistisches Reichsamt [Statistik des Deutschen Reichs, CDLIII, 2] (Berlin, 1936), p. 5; and Anton Reithinger, Stand und Ursachen der Arbeitslosigkeit in Deutschland (Berlin, 1932), p. 7. 
Table 2: Composition of the voting-age population of Eutin according to occupation (September 1930)

\begin{tabular}{|c|c|c|c|c|c|c|}
\hline \multirow[t]{2}{*}{ No } & \multirow{2}{*}{$\begin{array}{l}\text { Occupational } \\
\text { category }\end{array}$} & \multicolumn{3}{|c|}{ Number } & \multirow[t]{2}{*}{ Total } & \multirow[t]{2}{*}{ Percent } \\
\hline & & Ward 1 & Ward 2 & Ward 3 & & \\
\hline \multirow[t]{2}{*}{1} & professional, & & & & & \\
\hline & managerial & 26 & 19 & 6 & 51 & 1.13 \\
\hline \multirow{6}{*}{.3} & farmer & 17 & 9 & 9 & 35 & 0.77 \\
\hline & $\begin{array}{l}\text { merchant, store- } \\
\text { owner. }\end{array}$ & & & & & \\
\hline & businessman & 104 & 96 & 53 & 253 & 5.59 \\
\hline & merchant & 71 & 57 & 23 & 151 & 3.34 \\
\hline & store-owner & 7 & 21 & 10 & 38 & 0.84 \\
\hline & businessman & 26 & 18 & 20 & 64 & 1.41 \\
\hline 4 & handicraftsman & 155 & 152 & 195 & 502 & 11.10 \\
\hline \multirow[t]{3}{*}{5} & employee & 140 & 161 & 123 & 424 & 9.37 \\
\hline & technical, foreman & 39 & 75 & 27 & $14 I$ & 3.12 \\
\hline & shop, office & 101 & 86 & 96 & 283 & 6.26 \\
\hline \multirow[t]{3}{*}{6} & civil servant & 103 & 88 & 65 & 256 & 5.66 \\
\hline & teacher & 35 & 31 & 21 & 87 & 1.92 \\
\hline & other & 68 & 57 & 44 & 169 & 3.74 \\
\hline \multirow[t]{3}{*}{7} & worker & 122 & 165 & 269 & 556 & 12.29 \\
\hline & unskilled & 74 & 110 & 215 & 399 & 8.82 \\
\hline & skilled & 48 & 55 & 54 & 157 & 3.47 \\
\hline 8 & domestic servant & 110 & 109 & 49 & 268 & 5.93 \\
\hline 9 & pupil, student & 22 & 15 & 4 & 41 & 0.91 \\
\hline 10 & pensioner & 79 & 63 & 37 & 179 & 3.96 \\
\hline 11 & unemployed woman & 576 & 576 & 657 & 1809 & 40.00 \\
\hline \multirow[t]{2}{*}{12} & unknown & 61 & 50 & 38 & 149 & 3.29 \\
\hline & Total & 1,515 & 1.503 & 1,505 & 4,523 & 100 \\
\hline
\end{tabular}

assumption of power had not yet by the summer of 1933 significantly altered Germany's socio-economic situation from what it was twelve months earlier. The use of occupational data derived from sources originating more than two years apart is thus unavoidable, but surely permissible.

Occupations were also supplied for all but eight names on the list of Eutin Nazis. Those missing were obtained principally from information in the ZK. The occupations thereby established, eliminating purely sexual differentiations, totalled 158 separate designations. The data given in the list is as a rule employed in the following analysis; only if the ZK points unmistakably to another (usually related) occupation has the latter been preferred. The categories in Table 1 have been arranged in order beginning 
with the highest percentage of those independently employed among them. ${ }^{17}$

In order to interpret meaningfully the occupational division of Eutin's party membership, a control group is necessary. The best available one for this purpose would seem to be the town's population as a whole, which is given in Table 2 as derived from the voters' list for the Reichstag election of 14 September $1930 .{ }^{18} \mathrm{It}$ is not possible, or perhaps necessary, to analyse this compilation of over 4,500 names with the same precision as can be applied to the membership list. Nevertheless the figures given can claim to be tolerably accurate.

The first occupational category among Eutin's Nazis is that of professionals and employees and civil servants in managerial positions. It comprised two lawyers (one, Böhmcker, in private practice, the other a Syndicus or legal advisor to a company), a medical doctor, two architects (one of them simultaneously the director of a private technical school), an organist, the director of the local SA band, two self-employed meat inspectors, and the manager of a riding and driving school. ${ }^{19}$ No civil servant, though, fulfilled the requirement of the 1933 census - holding the rank of ministerial director or higher - for inclusion in this group. Predictably enough in an "urban" community, only six party members were farmers, the second category. All are considered to have been independent, although as many as half may have owned only a very small piece of land. Professional persons and managers as well as farmers were thus overrepresented in the Eutin party in comparison to their share of the total population, the former $(2.1 \%$ versus $1.1 \%)$ rather more so than the latter notwithstanding the particular appeal of the NSDAP among the agricultural population of Schleswig-Holstein before 1933.

17 In keeping with the 1933 census, all professionals, managers and farmers are counted as independent. However, only merchants, businessmen, store-keepers and handicraftsmen listed separately in the "Branchenverzeichnis der Stadt Eutin" in the Adressbuch (Einwohnerbuch) für Eutin und den gesamten Landesteil Lübeck (Landesteil des Freistaats Oldenburg) 1932 (Kiel and Eutin, 1932), pp. 42-54, are considered to have been proprietors of their own shop or firm.

18 The official Partei-Statistik, ed. by the Reichsorganisationsleiter der NSDAP ( 3 vols; Munich, 1935), is unsuitable for several reasons. It contains numerous distortions and possibly even deliberate falsifications. Cf. Kater, "Zur Soziographie", loc. cit., p. 126; Führer befiehl, p. 379; and Pridham, Hitler's Rise to Power, op. cit., pp. 186ff. Its occupational categories are also broader than those which can be determined for a more limited group such as the Eutin membership (cf. Partei-Statistik, I, p. 70).

19 Although four of these occupations were included among the "technically trained employees" in the 1933 census, the organist, the band leader and both meat inspectors were listed in the 1932 Branchenverzeichnis as independent. Other than the surgeon, the corporation lawyer was the only Eutin party member holding a doctoral degree and should therefore probably be classified as an "employee in a managerial position". 
Merchants, store-owners and businessmen (other than the operators of handicraft shops) make up the third occupational category. Eight of the 45 merchants (Kaufmänner) listed among the Eutin Nazis in fact had a different occupation according to information in either the ZK or the 1932 Adressbuch. Of the 37 remaining, only 15 could unquestionably be identified as independent proprietors (or the sons, and presumably heirs, of such); in the absence of clear evidence to the contrary, the others are therefore considered to have been sales personnel in a shop or business, in other words employees. ${ }^{20}$ An additional 14 party members dealt in various products from books and musical instruments, porcelain, coal and cigars, to vegetables, fish, cheese and cattle. Five innkeepers and a café owner; four trucking operators; three owners of automobile repair and rental businesses; two drugstore proprietors; two owners of plant nurseries; a brush manufacturer; ${ }^{21}$ a builder; a beer wholesaler; the owners of a hat shop and a movie house; a real-estate agent; and the proprietor of a laundry round out this category. It comprised $16 \%$ of the party membership and was therefore proportionally almost three times as numerous in the NSDAP as in Eutin as a whole.

Of the fifty handicraft guilds in Landesteil Lübeck, ${ }^{22} 29$ had at least one representative in Eutin's Nazi Ortsgruppe. The party members included in this fourth occupational category were all listed as either a master or journeyman belonging to one or another handicraft. The sole apprentice among them is included with the trade he was learning in accordance with the practice of the 1933 census. Finally, only those whose names appear separately in the 1932 Branchenverzeichnis of the Adressbuch are counted as independent proprietors of a handicraft shop; the remainder, including a number of masters, are considered to have been employees.

20 A completely satisfactory solution to the many problems raised by the all too elastic occupational designation of "Kaufmann" seems impossible in view of the absence of more exact data. No doubt some others were independent, such as those who operated their business under a name other than their own and therefore do not appear in the Adressbuch as proprietors. But to include all merchants in one category, as does Professor Kater ("Zur Soziographie", pp. 134-35), surely overlooks an important distinction.

21 Cf. Theodor Geiger, Die soziale Schichtung des deutschen Volkes. Soziographischer Versuch auf statistischer Grundlage (Darmstadt, 1967), p. 87: "Craftsmen have long since passed the point when [for instance] a brush maker with five journeymen thought he owed it to his reputation to describe himself as a "manufacturer'" Although this lone "manufacturer" among Eutin's Nazis had been a salesman rather than a handicraftsman. nevertheless as late as 1935 he apparently employed fewer than 20 workers. Report by the mayor of Eutin to the Regierungspräsident in Eutin on the results of the "Wahlen der Vertrauensmänner in den Betrieben", 23 April 1935, SAE, No 3482.

22 Cf. "Innungsverzeichnis", in: Jahresbericht der Handwerkskammer zu Altona für das Kalenderjahr 1935 (Altona-Ottensen, n.d.), pp. 35ff., SAE, No 1191. 
The preponderance of handicraftsmen is the most apparent characteristic of the occupational structure of the Ortsgruppe. ${ }^{23}$ Over $30 \%$ of its members belonged to this category. Compared with the number of handicraftsmen in the town's overall working population $(502$ or $11 \%$ in September 1930), this group was about three times as numerous within the local NSDAP as it was in Eutin as a whole. On the other hand, the proportion of Nazi handicraftsmen who owned their own business $(40.5 \%)$ almost exactly corresponded to the figure for all economically independent handicraftsmen in the town: 199 in the spring of 1932, or $39.6 \%$ of those counted in this category in September 1930. Although guild members were thus more likely than any other single occupational group to join the NSDAP in Eutin, journeymen and masters employed by someone else did so in proportionally greater numbers than shop-owners. Still, at least five heads (Obermeister) of guilds represented in Landesteil Lübeck who resided in Eutin were National Socialists for years before the party came to power; this no doubt accounts for the fewer changes effected among guild officers than in most other organizations when these were "co-ordinated" (gleichgeschaltet) in 1933. The Eutin Nazis who enjoyed an independent economic existence amounted to over one-fourth of the party membership. Although such individuals in the first two occupational categories by definition equalled $100 \%$, the proportion of handicraftsmen who were shop-owners was also high: almost $15 \%$ above the corresponding figure for the Ortsgruppe as a whole. Even more pronounced was the percentage of economically independent Nazis compared with the same group in the town's total population. ${ }^{24}$ In the spring of 1932 , the number of separate

23 On the attraction of handicraftsmen particularly in Schleswig-Holstein towards the NSDAP beginning in November 1929, see Peter Wulf, Die politische Haltung des schleswig-holsteinischen Handwerks 1928-1932 (Cologne and Opladen, 1969), esp. pp. 93-98, 130-35; more generally also Heinrich August Winkler, Mittelstand, Demokratie und Nationalsozialismus. Die politische Entwicklung von Handwerk und Kleinhandel in der Weimarer Republik (Cologne, 1973), esp. pp. 157ff.

24 This comparison can only be made very tentatively in view of the problems raised by the occupational designation "Kaufmann" (see note 20 ). Whereas 253 residents of Eutin were entered in the September 1930 voters' list as either "merchants", "store-owners", or "businessmen", a careful analysis of the Branchenverzeichnis counted altogether 243 businesses (excluding those of handicraftsmen) in the town. According to these figures, virtually $100 \%$ of all individuals in this category were therefore independent - a highly unlikely conclusion when the situation prevailing among the Nazi merchants alone is recalled: over $50 \%$ of these could not be identified as independent shop-owners. This discrepancy, the only one in the cross-tabulation of occupations in the Ortsgruppe and in the town, cannot be accounted for. 
businesses of every size and kind in Eutin was $528 .{ }^{25}$ Around $12 \%$ of the population (using the figures in the September 1930 voters' list, the only ones available) was therefore economically independent. In other words, such persons were approximately 2.3 times more numerous within the ranks of Eutin's Nazis than they were proportionally among the adult population of the town.

The fifth, and most complicated, category is that of so-called whitecollar employees (excluding those in managerial positions) working in industry, business, or government enterprises. Again following the 1933 census, these are divided into two sub-categories: first, the technically trained employees, foremen and other supervisory personnel, and secondly sales and office employees. Eutin Nazis among the former group were five foremen ${ }^{26}$ and an agricultural administrator; four technicians or engineers; two taxidermists; two artists and two surveyors; a technical inspector; a reporter; a private teacher; and a social worker. ${ }^{27}$ Also included are the 19 musicians who made up the SA band. The other sub-category comprised 13 shop assistants; seven office workers (including one trainee and two Nazi town senators); five salesmen; four bank employees; three clerks; two drugstore employees and two cashiers; the business managers of the Ortsgruppe and of the SA band; a book-keeper; a chief clerk; an office manager; and the accountant for the local Chamber of Agriculture. The white-collar employees were the second most numerous occupational category among party members. Taken together with the handicraftsmen, they made up almost half the Ortsgruppe. Employees were almost doubly over-represented in the NSDAP in relation to their share of the total town population. Notable in this respect is the proportionally even greater frequency of technical employees and supervisory personnel, who comprised only $3.1 \%$ of adult Eutiner but $8.3 \%$ of the Nazi membership. Somewhat more than one-quarter of all technically trained employees and foremen in the town were thus National Socialists.

25 This figure was perhaps somewhat reduced from that of almost two years earlier (when the voters' list for the election of September 1930 was compiled); notices of bankruptcy and closures appeared with increasing frequency in the AFL after the fall of 1931. On the other hand, some employees who thereby lost their jobs probably decided to go into business on their own, on however small a scale, thus maintaining and possibly even slightly increasing the number of economic "independents" among the population. 26 The 1933 census described foremen as specially qualified employees who had risen from the ranks of the skilled workers and who now directed the work of others, but conceded that it was not always clear whether an individual in this group as regards his social outlook should more properly be considered an employee or a worker. Cf. note 14 . 27 The latter was one of the three Nazis elected a town senator (Ratsherr) in November 1931 and described as such in the membership list. Since this post was only honourary, however, it seems more appropriate to include all three under their regular occupations. 
Minor civil servants comprise the sixth category. These were three postal and three probationary officials; a government messenger; a lay church official; and a retired police officer. Included as well are five elementaryand secondary-school teachers of various ranks, two of them pensioners. Contrary to the practice of the 1933 census, the latter are counted in the occupational category in which their social and political consciousness was undoubtedly formed. This group were only about half as strongly represented in Eutin's NSDAP as they were in the total population: $2.99 \%$ and $5.66 \%$, respectively. Their proportionally low representation is surprising in view of the absence of any ban or even informal pressure by the Oldenburg government upon its employees not to join the NSDAP: they were merely ordered after 1928 to refrain from wearing their party badges while on duty! The relative strength of the liberal parties (DVP, DDP) among teachers and civil servants, also the advanced age particularly of many of the senior ones assigned to Eutin before July 1932 (Böhmcker, for instance, was a quarter-century younger than his immediate predecessor as Regierungspräsident), may at least in part explain their lack of sympathy for the demagogic appeal of the youthful Hitler movement. ${ }^{28}$

41 Eutin Nazis in May 1932 were unskilled workers of different sorts. A sub-group in this seventh category are the various skilled workers who were neither handicraftsmen nor technically trained employees: eleven waiters; five truck and two cart drivers; four dairymen; two sailors; a riding-master; a gardener; and a telegraph lineman. Workers were about equally represented as Nazis and as citizens at large. Those with a skill, however, were much more readily attracted to the Nazi movement than those without: unskilled workers made up $8.7 \%$ of the party membership and $8.8 \%$ of the general population, those with special training $5.76 \%$ and only $3.47 \%$ of the two groups respectively. In this the skilled workers ressembled the technical employees; both showed noticeably greater susceptibility to Hitler's appeal than did the less well-educated members of their occupational category.

The eighth category, domestic servants (Hausangestellte), includes two young girls (Haustöchter) who according to the 1932 Adressbuch as well as the party membership list were not living with their own families and were therefore each likely employed in a household (one later called herself a "household employee" when applying for membership in the Nazi Women's Auxiliary); six housemaids; four male servants; a housekeeper;

28 Cf. LASH, Regierung Eutin, A III 2a, "Die Beamten der Regierung. Präsident, Räte, sowie ausserordentliche Mitglieder"; also private information from retired mayor Dr Hans-Ulrich Ricklefs. 
and a houseboy. The only party member listed as "without a profession" also belongs in this category, she is described in the ZK as a housekeeper. This group was significantly under-represented in the Ortsgruppe.

Pupils, one of them a high-school girl, and students comprise the ninth category. They made up nearly $2 \%$ of Eutin's Nazis, although they were less than half that proportion of the town's population with the right to vote in September 1930. A comparison between these two groups, though, is only possible to a limited degree because of their differing age qualification: "whereas Reichstag voters had to have reached their twentieth birthday, a party member could be up to two years younger. Thus of the nine National Socialists in this "occupational" category, two (i.e., almost one-quarter) had not yet reached the legal voting age by May $1932 .{ }^{29}$ Notwithstanding this reservation, it can be estimated that around $20 \%$ of all pupils and students in Eutin who were old enough to vote belonged to the NSDAP.

The tenth category were pensioners, one male and one female, whose previous occupations could not be determined. They were very considerably under-represented in the Ortsgruppe: proportionally nine times as many retired persons lived in the town as joined Hitler's movement. The final category is that of unemployed women. 23 Eutin Nazis are listed simply as "wives" (Ehefrauen). According to the 1932 Adressbuch, only one of these had a profession; she was a tailor and has therefore been counted among the handicraftsmen. Eleven widows (one a "captain's widow") are also included in this category, as are eight girls living at home and thus probably not employed elsewhere as domestic servants. The size of this category, $8.7 \%$ of Eutin's Nazis, appears much less significant when compared with either the proportion of such women in the town's overall population $(40 \%)$ or its own share among that group: a mere $2 \%$ of the more than 1,800 wives, widows, and unemployed girls in Eutin were National Socialists. ${ }^{30}$ Only when they are counted together with female party members who were employed (together 65 or $13.9 \%$ of the Ortsgruppe) and then compared with the proportion of women in the Nazi movement as a whole before 1933 - perhaps $7.5 \% 31$ - is the real strength of this group apparent. The unemployed women, in other words, constituted the difference between a female element in the Eutin party which other-

29 Cf. Alfred Milatz, Wähler und Wahlen in der Weimarer Republik, 2nd. ed. (Bonn, 1968), p. 41; and Führer befiehl, pp. 136ff. By the beginning of 1932, the Nazi Pupils' League (NS-Schülerbund) counted a further 30 members in Eutin. Kreisleiter Eutin to NSDAP Gau Schleswig-Holstein, 19 January 1932, USNA, T-81, roll 164, fr. 303278.

30 The total number of Eutin women in this category was actually somewhat higher; a large percentage of those entered in the 1930 voters' list as having "no stated occupation" (category 12 of Table 2) doubtless also belonged to it.

31 Cf. Partei-Statistik, I, p. 16. 
Table 3. Comparison by percentage of the occupational composition of the Nazi Ortsgruppe and the town of Eutin

\begin{tabular}{|c|c|c|c|c|}
\hline No & $\begin{array}{l}\text { Occupational } \\
\text { category }\end{array}$ & $\begin{array}{r}\text { NSDAP } \\
\text { May } 1932\end{array}$ & $\begin{array}{r}\text { Eutin } \\
\text { Sept. } 1930\end{array}$ & $\begin{array}{l}\text { Over- or under- } \\
\text { representation }\end{array}$ \\
\hline 1 & $\begin{array}{l}\text { professional, } \\
\text { managerial }\end{array}$ & 2.13 & 1.13 & 188.50 \\
\hline 2 & farmer & 1.28 & 0.77 & 166.23 \\
\hline 3 & $\begin{array}{l}\text { merchant, store- } \\
\text { owner, }\end{array}$ & & & \\
\hline & businessman & 15.99 & 5.59 & 286.05 \\
\hline 4 & handicraftsman & 31.56 & 11.10 & 281.79 \\
\hline 5 & employee & 17.27 & 9.37 & 184.31 \\
\hline & technical, foreman & 8.32 & 3.12 & 266.67 \\
\hline & shop, office & 8.96 & 6.26 & 143.13 \\
\hline 6 & civil servant & 2.99 & 5.66 & 52.83 \\
\hline 7 & worker & 14.50 & 12.29 & 117.98 \\
\hline & unskilled & 8.74 & 8.82 & 99.09 \\
\hline & skilled & 5.76 & 3.47 & 165.99 \\
\hline 8 & domestic servant & 3.20 & 5.93 & 53.96 \\
\hline 9 & pupil, student & 1.92 & 0.91 & 210.99 \\
\hline 10 & pensioner & 0.43 & 3.96 & 10.86 \\
\hline 11 & unemployed woman & 8.74 & 40.00 & 21.85 \\
\hline 12 & unknown & - & 3.29 & - \\
\hline & Total & 100 & 100 & \\
\hline
\end{tabular}

wise would have been approximately equal in proportion to that in the NSDAP throughout the Reich and one which in fact was almost twice as large.

Table 3 summarizes the occupational structures of the Ortsgruppe and of the town itself by comparing the percentages of party members in each category in May 1932 with their corresponding share of the total population of Eutin in September 1930. In this tabulation, the absolute numerical preponderance of the handicraftsmen in the NSDAP is more than made up for by the somewhat higher proportion of the town's merchants, shop-owners and businessmen who joined the party; the two groups were comparatively over-represented in the Ortsgruppe by $282 \%$ and $286 \%$, respectively. Both are almost equalled in their degree of overrepresentation by the sub-category of technically trained employees and foremen, who ranked third highest among all party members in this respect. Noteworthy also are the nearly similar figures for white-collar workers as a whole and for the sub-category of skilled blue-collar workers 
(184\% and $166 \%$, respectively); the latter were more than half again as numerous proportionally in the party as were unskilled workers. Remarkably low, at least in view of the susceptibility of white-collar employees in general for Nazi propaganda, ${ }^{32}$ is the over-representation among sales and office personnel, which is only slightly greater than that of workers as a whole - a category of Germans more resistant to Hitler's appeal than others. ${ }^{33}$ If pupils and students, professionals, managers and farmers were also over-represented among Eutin's Nazis, at the other end of the scale "pensioners, unemployed women, domestic employees and civil servants comprised the only under-represented occupational categories. Unskilled workers could (just barely) count themselves among this group, too.

A rather different overall picture emerges, though, if the occupational categories are broadly combined according to the probable social consciousness of the members in each. ${ }^{34}$ Thus if to the skilled and unskilled workers are added not only the domestic servants but also the handicraftsmen who were not economically independent, then 171 Eutin Nazis (36.5\% of the membership) can be described as "proletarian". (The comparable figure for the town's total population of voting-age was around one-quarter.) Similarly, the 95 non-managerial employees and civil servants, together with the 22 merchants who could not be identified as independent proprietors, made up a white-collar contingent of almost $25 \%$ in the Ortsgruppe. Only slightly larger was the "capitalist" group of professionals, farmers, independent handicraftsmen, shop-owners and businessmen: 129 members or $27.5 \%$. Altogether over $52 \%$ of the membership therefore belonged to the "middle class" (Mittelstand). (This designation applied proportionally to just half as many adults in Eutin as a whole.) Pupils, students, unemployed women and pensioners were all "without a gainful occupation"; they comprised the final $11 \%$ of the party's adherents (but $45 \%$ of Eutin's voters). According to this calculation, therefore, a significantly higher percentage of Nazis were in fact "workers" than described themselves as such. Nevertheless the clear majority of the Ortsgruppe was bürgerlich, if not (particularly in the case of most of the

32 See for example Jürgen Kocka, "Zur Problematik der deutschen Angestellten 19141933", in: Industrielles System und politische Entwicklung in der Weimarer Republik, ed. by Hans Mommsen, Dietmar Petzina and Bernd Weisbrod (Düsseldorf, 1974), esp. pp. 795-802.

${ }_{33}$ But cf. Max H. Kele, Nazis and Workers: National Socialist Appeals to German Labor 1919-1933 (Chapel Hill, N.C., 1972), esp. pp. 156, 203, 215, who emphasizes the relatively large working-class element in the NSDAP before 1933.

34 Cf. Geiger, Soziale Schichtung des deutschen Volkes, op. cit., pp. $77 \mathrm{ff}$. 
white-collar employees) in its economic position, then certainly according to its mentality. ${ }^{35}$

One last aspect of the occupational composition of the Ortsgruppe should be noted briefly: that of its leadership corps during the "struggle for power". Somewhat arbitrarily, this group has been confined to party and SA leaders (including two successive business managers of the Ortsgruppe and a propaganda director), the head of the Women's Auxiliary, the local SS and Hitler Youth leaders, the Nazi cultural plenipotentiary, and the three town senators elected in November 1931 - a total of 17 persons. Their professions were as follows: a lawyer and a surgeon; a brush manufacturer, a movie-house proprietor, a fish-store owner and a merchant; a master locksmith and a miller (who was also a farmer); a social worker and a foreman, two office workers, a business manager and a chief clerk; a probationary civil servant and a high-school art teacher; and one widow.

Although accounting for only $2 \%$ of the total membership of the Ortsgruppe, the category of professionals and managerial employees provided almost $12 \%$ of the leadership - and the two most important figures among Eutin's Nazis at that. The third occupational group (merchants, storeowners, businessmen) was represented within the party elite (23.5\%) in only a slightly greater proportion than among the general membership. Very much under-represented, however, were the handicraftsmen: at best only two of 148 were party leaders, exactly the same number as the first category which contributed less than $7 \%$ as many members to the Ortsgruppe. The increasing emphasis upon organization in the NSDAP after 1930 is reflected in the more than 35\% of Eutin's Nazi elite who were employees of one type or another, exactly double their proportion in the local party. This explanation applies equally to the civil servants - around $3 \%$ of the overall membership but $11.8 \%$ of the leaders - , who were thus four times as strongly represented among the latter as their number of members would warrant. ${ }^{36}$ The lone woman among the leadership, under-represented by most standards, at least adequately reflected the prevalent National Socialist principle that "women have no business in politics!"37 Finally, eight Eutin leaders were economically independent, almost twice the proportion as in the Ortsgruppe as a whole.

${ }^{35}$ Ibid., p. 55 and passim.

36 For a similar picture of the party's overall leadership corps in North Germany, see Orlow, History of the Nazi Party, op. cit., pp. 58, 119-21.

${ }^{37}$ Albert Krebs, Tendenzen und Gestalten der NSDAP. Erinnerungen an die Frühzeit der Partei (Stuttgart, 1959), pp. 56-57, who claims that this demand "was never asserted by the NSDAP as bluntly as its enemies maintained". Dr Pridham's conclusion, however, that in Bavaria women were virtually unknown among party leaders (Hitler's Rise to Power, pp. 203-04) was true as well for Eutin. 
To sum up: Eutin's Nazi party membership before Hitler became Chancellor was predominanily middle-class in character, but with a very significant "proletarian" element. Among the latter as well as among white-collar employees, those with specialized or technical training were particularly attracted to the party. So, too, were entrepreneurs of whatever magnitude, although they constituted only a substantial minority of the members. Handicraftsmen and women were especially numerous, but neither contributed much to the leadership of the local movement. That was concentrated in the hands of traditional elites, supported by administratively experienced clerical personnel. The town's overall population was imperfectly mirrored in the occupational composition of the Ortsgruppe; nevertheless the NSDAP could plausibly claim to be a Volkspartei, at least in that it embraced all groups of Eutin's citizens.

In addition to occupation, the $\mathrm{ZK}$ records both the birthdate and place of most party members. The ages of all 469 Eutin Nazis (those missing were obtained from the town's Registry Office) are grouped in Table 4 in relation to what in one fashion or another was the major event in the lives of most adult Germans before 1933: World War I. ${ }^{38}$ The first group were the pre-, the second group the elementary-school pupils in 1918. Group 3 were mostly still receiving occupational training or in secondary school when the war ended. The main burden of active military service was borne by the fourth, and to a lesser extent the fifth, groups. In exceptional cases, men from groups 6 and 7 , indeed even from 8 , also took part in the conflict; as a rule, however, groups 6 through 9 along with the under-18-year-olds and the women made up the home front. ${ }^{39}$

The age structure of the Ortsgruppe was very much in keeping with the pronounced youthfulness of the party as a whole. ${ }^{40}$ As might be expected

38 The pivotal significance of the years 1914-18 especially for future Nazis is stressed by Merkl, Political Violence, op. cit., pp. 28, 55, 154ff., 319, 321; and Peter Loewenberg. "The Psychohistorical Origins of the Nazi Youth Cohort", in: American Historical Review, LXXVI (1971), pp. 1457-1502.

39 This grouping corresponds rather closely to the experience of 15 Eutin party members for whom specific evidence of military service is randomly available. In all, 13 fought at the front including one born in 1901; but two others born the same year did not take part in the war. Eight who did were born between 1894 and 1899 (group 4), three others in 1888 and 1892 (group 5). A final man, born in 1875, was called up as a reservist in November 1916 - an exceptional example of patriotic duty, as he himself readily pointed out.

40 See for example Orlow, History of the Nazi Party, pp. 56-57; and Merkl, Political Violence, pp. 12-13 and Pt III, passim. 
Table 4: Composition of the Nazi Ortsgruppe in Eutin according to age in relation to World War I

\begin{tabular}{lllrrrrrr} 
No & Age & Year of & Number & Percent & \multicolumn{2}{c}{ Male } & \multicolumn{2}{c}{ Female } \\
& $1914-18$ & birth & & & No & No & $\%$ \\
1 & under 5 & $1915-13$ & 19 & 4.05 & 16 & 3.41 & 3 & 0.64 \\
2 & $6-13$ & $1912-05$ & 156 & 33.26 & 133 & 28.36 & 23 & 4.90 \\
3 & $14-17$ & $1904-01$ & 69 & 14.71 & 65 & 13.86 & 4 & 0.85 \\
4 & $18-25$ & $1900-1893$ & 78 & 16.63 & 70 & 14.93 & 8 & 1.71 \\
5 & $26-30$ & $1892-88$ & 38 & 8.10 & 33 & 7.04 & 5 & 1.07 \\
6 & $31-35$ & $1887-83$ & 37 & 7.89 & 33 & 7.04 & 4 & 0.85 \\
7 & $36-40$ & $1882-78$ & 22 & 4.69 & 18 & 3.84 & 4 & 0.85 \\
8 & $41-50$ & $1877-68$ & 35 & 7.46 & 27 & 5.76 & 8 & 1.71 \\
9 & over 52 & $1866-52$ & 15 & 3.20 & 9 & 1.92 & 6 & 1.28 \\
& & & -469 & 100 & 404 & 86.14 & 65 & 13.86
\end{tabular}

in view of the small number of pensioners and the proportionally high representation of pupils and students, 225 Eutin members or $47.9 \%$ were under thirty years of age, a further $102(21.7 \%)$ were between thirty and forty in May 1932 - altogether nearly $70 \%$ were born after 1892. The average age of the membership was 34.8 years, with women generally five years older than that; less than $15 \%$ of Eutin's Nazis were over fifty. The leadership corps was younger still: six (35\%) were under thirty, seven (41\%) under thirty-seven years, Böhmcker's age when he became Regierungspräsident. Their average age was 34.29 years; only the leader of the Women's Auxiliary was older than forty-four.

Noteworthy also was the age distribution in relation to World War I. Almost 53\% of the male members were in most cases still too young, and a further $22 \%$ likely too old, to have been called up for battlefield service. Taken together with all of the women, well over three-quarters of the Ortsgruppe therefore probably only experienced the war second-hand. The so-called "front soldiers" were thus a decided minority among Eutin's Nazis as a whole in 1932. Not, though, among the leaders, at least seven of whom (over $40 \%$ ) served in either the army or navy between 1914 and 1918 , most of them at the front. Except for the leadership corps, however, the war as a personal Kampferlebnis (fighting experience) evidently played no role in the decision of most Eutiner to join the militant NSDAP.

The two most remarkable features of the birthplaces of Eutin's Nazis are, first, that $70 \%$ lay within the pre-war boundaries of the Prussian province of Schleswig-Holstein (including the town itself and Oldenburg's Landesteil Lübeck) and, secondly, that $80 \%$ counted fewer than 10,000 inhabitants 
as late as $19100^{41}$ The membership was thus predominantly local and either rural $^{42}$ or small-town in its origins. Almost $45 \%$ had probably spent most of their lives (except for military service before and/or during World War I) within the narrow confines of the Landesteil and its "capital". In contrast, the proportion of party members born in places larger than Eutin is rather surprising in view of the prevalent movement of Germany's population since the mid nineteenth century into the large industrial centers of the Reich, and constitutes an interesting example of the reverse phenomenon "of "fleeing the city" - perhaps either a reflection of, or an impetus behind, the pronounced anti-urban bias in National Socialist propaganda. ${ }^{43}$ This $20 \%$ of the membership included 40 born in Lübeck, Kiel and Hamburg, the closest large cities; but there were also three each from Berlin and Hanover, two each from Munich and Leipzig, and one each from Dresden, Düsseldorf, Essen, Bochum, Krefeld and Mainz - all places with over 100,000 citizens in 1910. The musicians who made up the SA band and especially females were over-represented among those born in such midle- and large-size cities.

Among the leaders, the pattern was somewhat different. Only ten (less than $60 \%$ ) were born in either Landesteil Lübeck or in the remainder of Schleswig-Holstein. Particularly notable, though, is the number born outside the Reich. Although only six Eutin Nazis belonged in this category, two were leaders - evidence even at the local level of the potent appeal of the NSDAP among Auslandsdeutsche (Germans from abroad). ${ }^{44}$ Five, or one-third of those born within Germany, came from larger cities. Thus, on the whole, the leadership of the Ortsgruppe had rather more cosmopolitan - or at least varied - origins than did the bulk of the membership.

\section{IV}

Although at least one resident of Eutin found his way into the NSDAP

41 Cf. Meyers Orts- und Verkehrs-Lexikon des Deutschen Reichs, 5th completely rev. and exp. ed., ed. by E. Uetrecht (Leipzig and Vienna, 1912-13); and Müllers Grosses Deutsches Ortsbuch, 8th rev. and exp. ed., ed. by Friedrich Müller (Wuppertal-Barmen, 1949). Some half-dozen birthplaces could not be identified beyond dispute because of the duplication of town names.

42 Most places of birth with fewer than 1,000 inhabitants (30\% of the total) were either villages or else large landed estates which characterized the East Holstein countryside before World War I. Cf. Statistische Beschreibung der Gemeinden des Fürstentums Lübeck, ed. by Paul Kollmann (Oldenburg, 1901), esp. pp. 190-91; and Heberle, Landbevölkerung und Nationalsozialismus, op. cit., esp. $63 \mathrm{ff}$.

${ }^{43}$ See for example David Schoenbaum, Hitler's Social Revolution: Class and Status in Nazi Germany (Garden City, N.Y., 1966), pp. 46f.

44 Cf. Merkl, Political Violence, pp. 105ff. 
Table 5: Composition of the Nazi Ortsgruppe in Eutin according to party number and date of joining (May 1932)

\begin{tabular}{|c|c|c|c|c|c|c|}
\hline No & Joined & Party number & No & Male & Fem. & $\%$ \\
\hline 1 & 13.6 .25 & $7,569-70$ & 2 & 2 & & 0.48 \\
\hline 2 & 1.12 .25 & 22,833 & 1 & 1 & & 0.24 \\
\hline 3 & 11.1 .26 & $27,601-05$ & 2 & 2 & & 0.48 \\
\hline 4 & 17.5 .26 & $36,401-06$ & 2 & 2 & & 0.48 \\
\hline 5 & 13.8 .26 & 42,718 & 1 & 1 & & 0.24 \\
\hline 6 & 9.9 .26 & $43,796-97$ & 2 & 2 & & 0.48 \\
\hline 7 & 1.5 .27 & 63,308 & 1 & & 1 & 0.24 \\
\hline 8 & 1.3.28 & 77,391 & 1 & 1 & & 0.24 \\
\hline 9 & 1.5 .28 & 85,802 & 1 & 1 & & 0.24 \\
\hline 10 & 1.11 .28 & 102,255 & 1 & 1 & & \\
\hline 11 & 1.11 .28 & $103,933-34$ & 2 & 2 & & 1.45 \\
\hline 12 & 1.11 .28 & $104,320-26$ & 3 & 3 & & \\
\hline 13 & 1.12 .28 & $106,148-50$ & 3 & 3 & & 0.72 \\
\hline 14 & 1.1 .29 & $110,206-10$ & 3 & 3 & & 0.72 \\
\hline 15 & 1.2 .29 & $113,415-19$ & 5 & 5 & & 1.20 \\
\hline 16 & 1.3 .29 & $119,744-53$ & 4 & 4 & & 0.96 \\
\hline 17 & 1.4 .29 & $123,410-32$ & 3 & 3 & & 0.72 \\
\hline 18 & 1.5 .29 & $125,845-56$ & 7 & 7 & & 1.69 \\
\hline 19 & 1.6.29 & $131,831-33$ & 2 & 2 & & \\
\hline 20 & 1.6 .29 & $132,607-15$ & 4 & 4 & & 1.93 \\
\hline 21 & 1.6 .29 & $133,883-84$ & 2 & 2 & & \\
\hline 22 & 1.7 .29 & $138,291-97$ & 2 & 2 & & 0.72 \\
\hline 23 & 1.7 .29 & 140,623 & 1 & 1 & & 0.12 \\
\hline 24 & 1.9 .29 & $148,469-71$ & 2 & 2 & & 0.72 \\
\hline 25 & 1.9 .29 & 151,354 & 1 & 1 & & \\
\hline 26 & 1.10 .29 & $158,328-57$ & 18 & 17 & 1 & 4.34 \\
\hline 27 & 1.11 .29 & $159,868-89$ & 10 & 10 & & 3.86 \\
\hline 28 & 1.11 .29 & $166,351-62$ & 6 & 6 & & 3.86 \\
\hline 29 & 1.12 .29 & $177,300-11$ & 4 & 1 & 3 & \\
\hline 30 & 1.12 .29 & $177,426-38$ & 6 & 2 & 4 & 3.13 \\
\hline 31 & 1.12 .29 & $177,765-73$ & 3 & 3 & & \\
\hline 32 & 1.1 .30 & $180,215-22$ & 3 & 3 & & 0.72 \\
\hline 33 & 1.2 .30 & 192,679 & 1 & 1 & & \\
\hline 34 & 1.2 .30 & $193,433-34$ & 2 & $i$ & 1 & 0.72 \\
\hline 35 & 1.3 .30 & $206,894-95$ & 2 & 2 & & 0.48 \\
\hline 36 & 1.4 .30 & 226,082 & 1 & l & & 0.24 \\
\hline 37 & 1.5 .30 & 241,154 & 1 & 1 & & 0.24 \\
\hline 38 & 1.6 .30 & 261,256 & 1 & 1 & & 0.48 \\
\hline 39 & 1.6 .30 & 261,404 & I & 1 & & 0.48 \\
\hline 40 & 1.8 .30 & $275,895-96$ & 2 & 2 & & \\
\hline 41 & 1.8 .30 & 277,121 & 1 & 1 & & 1.93 \\
\hline 42 & 1.8 .30 & $282,681-89$ & 4 & 4 & & \\
\hline 43 & 1.8 .30 & 282,837 & 1 & 1 & & \\
\hline
\end{tabular}




\begin{tabular}{|c|c|c|c|c|c|c|}
\hline No & Joined & Party number & No & Male & Fem. & $\%$ \\
\hline 44 & 1.10 .30 & $314,249-50$ & 2 & 1 & 1 & \\
\hline 45 & 1.10 .30 & 316,845 & 1 & 1 & & \\
\hline 46 & 1.10 .30 & $317,792-94$ & 3 & 3 & & 1.69 \\
\hline 47 & 1.10 .30 & 322,978 & 1 & 1 & & \\
\hline 48 & 1.11 .30 & $354,511-18$ & 4 & 4 & & \\
\hline 49 & 1.11 .30 & 367,477 & 1 & 1 & & 2.41 \\
\hline 50 & 1.11 .30 & $367,663-71$ & 5 & 5 & & \\
\hline 51 & 1.12 .30 & $373,946-77$ & 16 & 14 & 2 & \\
\hline 52 & 1.12 .30 & $381,846-57$ & 7 & 4 & 3 & 5.54 \\
\hline 53 & 1.1 .31 & $413,221-44$ & 10 & 10 & & 2.41 \\
\hline 54 & 1.2 .31 & $419,773-74$ & 2 & 2 & & 0.96 \\
\hline 55 & 1.2 .31 & $432,465-68$ & 2 & 1 & 1 & 0.96 \\
\hline 56 & 1.3 .31 & $459,165-71$ & 3 & 3 & & 0.96 \\
\hline 57 & 1.3 .31 & 487,264 & 1 & 1 & & 0.96 \\
\hline 58 & 1.4 .31 & 506,713 & 1 & 1 & & 0.24 \\
\hline 59 & 1.5 .31 & $520,429-39$ & 10 & 8 & 2 & 2.41 \\
\hline 60 & 1.6 .31 & 547,369 & 1 & 1 & & \\
\hline 61 & 1.6 .31 & $558,418-44$ & 19 & 17 & 2 & 5.06 \\
\hline 62 & 1.6 .31 & 564,202 & 1 & 1 & & \\
\hline 63 & 1.7 .31 & $584,645-61$ & 6 & 6 & & \\
\hline 64 & 1.7 .31 & $588,099-106$ & 5 & 2 & 3 & 2.65 \\
\hline 65 & 1.9 .31 & $626,767-76$ & 6 & 4 & 2 & 1.45 \\
\hline 66 & 1.10 .31 & $647,487-90$ & 2 & 2 & & \\
\hline 67 & 1.10 .31 & $648,089-93$ & 3 & 3 & & \\
\hline 68 & 1.10 .31 & $682,041-51$ & 7 & 7 & & 3.01 \\
\hline 69 & 1.10 .31 & $683,759-62$ & 3 & 3 & & \\
\hline 70 & 1.11 .31 & $703,485-93$ & 5 & 4 & 1 & \\
\hline 71 & 1.11 .31 & 703,928 & 1 & 1 & & 11.08 \\
\hline 72 & 1.11 .31 & $726,690-751$ & 40 & 34 & 6 & \\
\hline 73 & 1.12 .31 & $774,675-726$ & 36 & 30 & 6 & \\
\hline 74 & 1.12 .31 & $799,605-66$ & 32 & 26 & 6 & 16.39 \\
\hline 75 & 1.2 .32 & $957,476-518$ & 23 & 22 & 1 & 5.54 \\
\hline 76 & 1.3 .32 & $1,019,455-80$ & 14 & 13 & 1 & 3.37 \\
\hline 77 & 1.4 .32 & $1,047,881-86$ & 5 & 5 & & 1.20 \\
\hline 78 & 1.5 .32 & $1,114,854-64$ & 8 & 7 & 1 & 1.93 \\
\hline 79 & 1.8 .32 & $1,244,924$ & 1 & $i$ & & 0.24 \\
\hline 80 & 1.5 .33 & $2,730,590$ & 1 & 1 & & 0.48 \\
\hline 81 & 1.5 .33 & $2,756,348$ & 1 & 1 & & 0.48 \\
\hline \multirow[t]{2}{*}{82} & 1.5 .37 & $3,966,800$ & 1 & 1 & & 0.24 \\
\hline & Total & & 415 & 367 & 48 & 100 \\
\hline
\end{tabular}


prior to Hitler's unsuccessful Putsch of November $1923,{ }^{45}$ an Ortsgruppe was only established in the town in May 1925 following the refounding of the party after Hitler's release from Landsberg prison. ${ }^{46}$ The seven cofounders consisted of a butcher, a carpenter and a baker (all journeymen), a technician and an electrician, a bank trainee, and a lay official of the Evangelical-Lutheran Church, who together received party numbers 7,566-72. The subsequent growth of the membership will be examined in what follows, employing data found in the various collections of the BDC. 411 persons from the original list could be positively identified as National Socialists up to May 1932, and a further four before May 1937, along with their party number and the date of their formal acceptance into the NSDAP. ${ }^{47}$ Table 5 summarizes this information, and shows the percentage of the identifiable members (that is, 415 ) who entered the party at each date.

The development of the NSDAP in Eutin can be divided into five phases. The first reaches from the founding of the Ortsgruppe until the eve of the Reichstag and Oldenburg Landtag elections on 20 May 1928, in which the NSDAP reappeared as a party in Landesteil Lübeck for the first time since 1924. ${ }^{48}$ It includes the first of two speeches Hitler made in the town, in May 1926. The second period concludes with the energetic campaign waged by the National Socialists against the Young Plan in support of the so-called "Freedom Law" and the referendum on it in December 1929.49 The third phase takes in three elections - for the Reichstag on 14 September, the town council on 23 November and the assembly for Landesteil Lübeck (Landesausschuss) on 30 November $1930^{50}$

45 He was a bank clerk from Lübeck, born in 1903, who only lived in Eutin between April and December 1923; he joined the party on 25 October. According to the ZK, he did not re-enter the NSDAP until 1937. I am grateful to Jürgen Genuneit for this reference.

46 Cf. Diercks, "Kampf und Aufstieg der NSDAP in Eutin", in: Denkschrift, op. cit., p. 49.

47 For one additional Nazi identified, no membership number or date of entry could be found.

48 The party had received 148 votes in the Reichstag election of December 1924, and only three more than that in 1928 , although 220 voters in the town simultaneously supported the NSDAP in the Landtag ballot (the Nazis had not put up an independent slate in the previous state election). A total of 28 Eutiner had voted for General Ludendorff, the party's candidate in the first presidential election in March 1925. AFL, 27 April 1925 and 21 May 1928; and Diercks, "Kampf und Aufstieg”, loc. cit., pp. 48, 60-61.

49 Ibid., pp. 74, 76. About one-third of the eligible voters in Eutin supported the NaziNationalist initiative. Volksentscheid über das "Freiheitsgesetz" am 22. Dezember 1929 , SAE. No 587.

50 The NSDAP obtained 39,45 and $52 \%$, respectively, of the votes cast in the town during these elections. AFL, 15 September, 25 November and 1 December 1930; also Diercks, "Kampf und Aufstieg", pp. 83-84, 86. 
- as well as the initial outbursts of political violence in Eutin: a bloody clash between members of the SA and the Reichsbanner (the republican defense organization) during an election address by Dr Julius Leber on 27 November and a public assault upon a Social Democratic Landtag deputy by several SA troopers the following day. The Landtag election on 17 May $1931,{ }^{51}$ and especially the death of an SS man during a street battle between Reichsbanner adherents and Nazis on 9 November 1931 and the intensified political struggle which followed, make up the fourth and dec- isive period of the party's history during its climb to power. The final phase again includes several election campaigns (the presidential elections of 13 March and 10 April 1932, the popular initiative and referendum to dissolve the Oldenburg Landtag between December 1931 and April 1932), and culminated in the Landtag election on 29 May 1932, which gave Oldenburg and its Landesteil Lübeck a National Socialist government.

As Table 5 shows, no fewer than 164 of the 411 members of the Ortsgruppe in May 1932 (40\%) joined the NSDAP after 1 November 1931. A further 122 had only signed up during the previous twelve months. Almost $70 \%$ of those who could be identified had become National Socialists since October 1930. The party in Eutin as it was constituted on the date of the Nazi assumption of power in Oldenburg was thus numerically very substantially the product of the membership intake during the almost two years following the decisive electoral breakthrough of the movement on the national and local levels beginning in the fall of 1930 . Nonetheless 125 members (including all but four of the leaders) could claim already to have been active on Hitler's behalf at a time when there was still no indication of his future success at the polls. Three per cent of the membership in May 1932 could even wear the golden party badge - that is, they had numbers under 100,000 . In this regard, women were somewhat less attracted to the early NSDAP than were men: the later head of the Women's Auxiliary was the sole long-time female party member (she joined in May 1927), and only $20 \%$ of the females compared with $28 \%$ of the males had become Nazis prior to September 1930.

Among the different occupational categories, some fluctuation in the time of entrance into the party is noticeable. The most striking is the steady drop in the proportion of workers among new members of the Ortsgruppe between November 1928 and December 1931. Whereas a total of 17 out of 92 Nazi recruits during the second phase of the party's history in Eutin described themselves as workers, only one more than this among the 186 who joined during 1931 can be so classified - a proportional decline of ${ }^{51}$ Eight times as many Eutin voters as in the 1928 Landtag election cast their ballots for the Nazis - a total of 1,735. AFL, 18 May 1931. 
almost $50 \%$ between the two periods. The slight increase of workers among new Nazis during 1932 (six out of fifty, or 12\%) was still less than the share of this occupational category among the identifiable membership as a whole (12.9\%). This development was in keeping with the general trend of party propaganda after 1928 away from a "revolutionary socialist" appeal to urban industrial workers and towards the predominantly nationalistic middle-class electorate living in rural areas and small towns. ${ }^{52}$ In contrast to workers, white-collar employees comprised a generally increasing proportion among new members after November 1928, presumably also a reflection of this switch in propaganda emphasis.

Among the new Nazis of the middle three periods, businessmen and handicraftsmen were fairly equally distributed, although the latter show the highest share of joiners from a single occupational group during any one phase $(40 \%)$ precisely during the final months before the party came to power. Until the end of 1931, women without employment entered the Ortsgruppe in quite regular proportions - between $7.7 \%$ and $10 \%$ of new members in each period - , notwithstanding the generally small numerical contingent of females during the first five years of its existence. Two groups were proportionally well represented only among the earliest and the latest recruits: the professionals and managerial employees as well as the civil servants. Half of the former joined the NSDAP before December 1929, and a further 25\% in the short time between February and May 1932. The identical pattern was even more pronounced among government personnel: they made up almost one-quarter of the most senior members, but then supplied only one new recruit until October 1931, after which date nearly $70 \%$ of this occupational group who did so became Nazis. Also late joiners - but explicably so in view of their age and "occupation" - were the seven members still designated as pupils and students in May 1932, all of whom had signed up only since January 1930.

Much more evenly distributed than in the case of several individual occupational categories was Nazi recruitment among economically independent residents of Eutin. Only the proportion of such persons among the oldest 13 members in the Ortsgruppe in May 1932 (7.7\%) was particularly low; in contrast, recruits from this group were heavily overrepresented among those who joined the party during the second time

52 Cf. Orlow, History of the Nazi Party, pp. 117-18, 153, and chs IV and V passim. The strong trade-union and social-democratic attachments of Eutin workers at least until the end of 1931 may explain the relative lack of Nazi propaganda success among them. Johannes Rathkamp and Karl Broschko, Geschichtlicher Úberblick über die Vereinsund Organisationsbewegung der Eutiner Arbeiterschaft (Eutin, 1929); and interview with former Eutin Reichsbanner leader Adolf Buhrke, Hamburg, 14 January 1975. 
period. Possibly this dramatic increase can be explained as part of the movement's increased interest in winning the support of small-town businessmen after the Reichstag election in May $1928 .{ }^{53}$ In any case, the share of independent merchants, handicraftsmen and professionals among new members (almost 40\%) was not reached again in any phase before 1933, although their proportions rose steadily between January 1930 and May 1932. At least one conclusion thus appears justified: about one-third of the "propertied class" among the town's National Socialists (however modest their wealth might have been) joined the NSDAP prior to December 1929, before much hope existed that their new party would ever come to power in Oldenburg, much less in Berlin. Nor after that date was the movement suddenly "stormed" by this group of relatively prosperous Eutiner, as the party's claim to share power in the Reich as well as on the local level steadily grew stronger thanks to its increasing electoral support. The economically independent, on the contrary, constituted the stable backbone of the Ortsgruppe: numerically very well represented among the membership at a fairly early point, then loyal to the party for years on end, and at the same time a regular source of new recruits. Especially in financial terms, ${ }^{54}$ their adherence was undoubtedly of crucial importance for the work, perhaps even the survival, of the party in Eutin.

Those members who, on the other hand, did not enjoy economic independence of course joined the NSDAP in exactly opposite proportions during each of the five phases of its history. Overall they comprised more than $70 \%$ of the Ortsgruppe; aside from the first contingent of recruits, who were almost all dependent employees and workers, their share of new members never varied much beyond this average. The "socialist" appeal of the NSDAP before May 1928 probably accounts for the humble status of most of its earliest members; even the lone "independent" among them, Böhmcker, was only a fledgling lawyer. The sharp relative decline in new membership among the employed between November 1928 and December 1929 was nevertheless more than a merely temporary reflection of the NSDAP's heightened attention towards the pre-eminently bourgeois elements in the population. Although over three-quarters of those who joined the Ortsgruppe during 1930 were not independent (compared with only about three-fifths during the preceding twelve months), this proportion steadily declined again until May 1932. In this respect at least, the Nazi party in Eutin progressively became rather more a Klassenpartei than a

53 Cf. Orlow, History of the Nazi Party, pp. $131 \mathrm{ff}$.

54 For a general assessment of the significance of members' dues and internally generated revenue for the party's continued existence before 1933, see Alan Bullock, Hitler: A Study in Tyranny, rev. ed. (New York, 1962), pp. 132-33, 171-72. 
Volkspartei: during each individual time-span after November 1928, the proportional share of those who were employed among new recruits was always between $11 \%$ and $26 \%$ less than their representation in the votingage population of the town as a whole.

As for the age pattern of members when they first joined the party, those who did so while between the ages of 18 and 25 were proportionally by far the most strongly represented among recruits during each period in the growth of the Ortsgruppe. The second-youngest category as well (those under 30 years of age) never had a share of new members less than that of any older group in any phase between 1925 and the end of 1931. Notwithstanding this constant intake of youthful members, however, the average age of the Ortsgruppe almost certainly rose over seven years: whereas the 13 veteran Nazis, who had joined before May 1928, had averaged 31 years of age upon entering the NSDAP, the average age of the 469 Eutin Nazis in May 1932 was about three years older.

An answer to the important question why persons from each group joined the party at a particular time can at best only be surmised. Thus the seven women who on 1 December 1929 were accepted into the Ortsgruppe were probably attracted to it by the simultaneous creation of a Nazi Women's Auxiliary unit in the town. Family considerations, too, might have played a significant motivational role: over a quarter of the persons on the list had one or more close relatives who were also members (nearly $50 \%$ of the females fell in to this category, and in the great majority of cases they were preceded as Nazis by a father, husband, brother or son). For most, though, a reason for joining is not readily discernible. For one thing, there was no firm relationship between the date of entering the NSDAP as given in the $\mathrm{ZK}$ and that on which an application for membership was signed; a considerable delay between the two was not unusual, depending upon the promptitude with which the Ortsgruppe and the Gau administrations processed it. ${ }^{55}$ This was especially so in the case of Eutin, where party business was often conducted in a slipshod fashion. The formal entrance date thus provides only a general indication as to when an individual actually decided to join the NSDAP.

The sort of personal biographical information about each Eutin Nazi which would help close this gap is not available. What can be demonstrated from the data in Table 5 is that, as a rule, the party experienced its greatest rush of applicants during election campaigns, when its overall propaganda activity was greatly intensified. Curiously enough, though, neither of the two public speeches Hitler delivered in the town in May

${ }^{55}$ Cf. Hans Buchheim, "Mitgliedschaft bei der NSDAP", in: Gutachten des Instituts für Zeitgeschichte (Munich, 1958), pp. $314 \mathrm{ff}$. 
1926 and May 1931 had the effect which might have been expected of accelerating recruitment dramatically. In the 90 days following the latter address before an estimated crowd of 4,000 , only some thirty persons entered the Ortsgruppe. By comparison, between October and December 1931, when no prominent Nazi speaker visited Eutin but when the most bitter political clashes of the Weimar years in the town took place, at least 129 residents became National Socialists. Violence evidently did nothing to check, and may even have increased, the flow of new members into the party.

The relationship between membership in the Nazi party and in its paramilitary arm, the SA, can also be examined at least to a limited extent from data pertaining to the movement in Eutin. Only a single list of the town's SA members prior to 1933, together with their occupations, seems to have survived. It dates from the summer of 1929, and is among the personal papers of the then SA Standartenführer (later Obergruppenführer) Böhmcker. ${ }^{56}$ The list includes 54 names from Eutin, of whom all but eight could be identified in the BDC as party members. At least $87.5 \%$ of the town's SA unit were thus simultaneously enrolled in the NSDAP, a proportion almost identical with that of positively ascertainable Nazis in the May 1932 membership list. But since every SA trooper after June 1927 was obliged also to belong to the party, it can be assumed that all those on the list indeed did so. ${ }^{57}$ The reverse, however, was not true; although in some localities all applicants for the NSDAP were compelled to join the SA as well within a few weeks, ${ }^{58} 30$ of the 54 male Eutiner who according to Table 5 became National Socialists up to 1 July 1929 evidently did not. (Of these, almost two-thirds were over 30 years of age and hence thought perhaps too senior for rugged service in the SA; that was doubtless so in the case of two severely wounded veterans of World War I.)

The "proletarian" character of the SA in Eutin seems indisputable. Nearly two out of every five brownshirts in 1929 were either unskilled or trained workers, compared with only $17 \%$ in this category among those

56 These are now deposited in LASH.

57 Cf. Orlow, History of the Nazi Party, p. 101; also Werner Jochmann, Nationalsozialismus und Revolution. Ursprung und Geschichte der NSDAP in Hamburg 1922-1933 (Frankfurt/M., 1963), pp. 266-68.

58 Cf. for example Der NSDAP Kreis Lübeck. Werden und Wachsen. Die Kampfjahre, ed. by the Kreisleitung Lübeck der NSDAP (Lübeck, 1935), pp. 11, 18; and Merkl, Political Violence, p. 602 . In Hesse, on the other hand, only one in three party members belonged to the SA at the end of 1931. Eberhart Schön, Die Entstehung des Nationalsozialismus in Hessen (Meisenheim am Glan, 1972), pp. 140, 142. 
party members who had joined the Ortsgruppe before December 1929 and still belonged to it in May 1932. If to these are added the handicraftsmen (who in almost every case were probably too young to own their own shop), a clear majority of the SA was "proletarian" whereas no more than $34 \%$ of the party membership at the end of 1929 could be so described. Whitecollar employees, along with all but the two merchants and businessmen who were independent (one was listed as a manufacturer, the other managed a small brush factory), made up an additional $30 \%$ of the troop. The latter pair, a pensioned non-commissioned officer, five farmers (some of whom may actually have been agricultural workers on nearby estates), a doctor and a lawyer (Böhmcker) - together 15\% - rounded off the unit. In all likelihood, hardly more than a half-dozen Eutin SA members enjoyed a middle-class existence. Under Böhmcker and in addition to the unit's medical officer, the seven subordinate troop leaders comprised five workers, a book-keeper, and the ex-army sergeant. ${ }^{59}$

The youthfulness of the SA was equally pronounced. Almost $60 \%$ were 25 years of age or less in July 1929, whereas only $35 \%$ of the then party membership was as young. Just four brownshirts, including the troop doctor, were older than 35; proportionally five times as many members of the Ortsgruppe in December 1929 belonged in that age group. Within an already youthful party, the SA constituted both the youngest and the most dynamic element, as its dominant role in the "capture" of East Holstein for the NSDAP testified.

\section{VI}

The examination up to this point of the composition of the Eutin Ortsgruppe has been restricted by at least one important shortcoming of the May 1932 membership list: its incompleteness. That is to say, the list has been presumed to comprise the names of the 469 persons who made up the membership at that time (including at least four who only joined the movement later but were likely known already as party activists in mid 1932). It follows that it is the membership structure as recorded in the list, and further identified in the collections of the BDC, which alone could be analysed above. But the list reveals nothing about two other categories of Nazi members: those who originally joined the NSDAP while living in the town but who moved to another Ortsgruppe before it was compiled, as well as those who quit or were excluded from the party prior to May 1932. Although the $\mathrm{ZK}$ regularly notes changes in residence and standing for

59 Cf. Michael H. Kater, "Zum gegenseitigen Verhältnis von SA und SS in der Sozialgeschichte des Nationalsozialismus von 1925 bis 1939", in: Vierteljahrschrift für Sozialund Wirtschaftsgeschichte, LXII (1975), pp. 343-44. 
each member, what can be said about one-time National Socialists in Eutin who were not located among the millions of records in the BDC merely because they do not appear in the membership list? An answer to this question would not only help complete the analysis of the Ortsgruppe but, perhaps more important, -might also throw light upon the still elusive problem of the general fluctuation in Nazi membership during the "struggle for power". ${ }^{60}$

As can be seen in Table 5, the great majority of identifiable members of "the Ortsgruppe held a party number which lay within a more or less complete series of numbers; for example, the 18 who joined on 1 October 1929 all received numbers between 158,328 and 158,357 . Leaving aside the 27 members whose numbers did not (including all four who joined the NSDAP only after May 1932), an examination of the remaining 55 series indicates that between the first and last figures in each a total of 310 membership numbers are "missing". Were any, or all, of these numbers assigned to former Eutin Nazis rather than to members who joined some other Ortsgruppe? The existence of a numbered membership list for the post-1925 party as a whole, such as Professor Kater used to analyse the early NSDAP, ${ }^{61}$ would of course quickly provide the answer: the "missing" numbers could be checked against it to ascertain to whom they belonged. The absence of any such comprehensive list, however, means that the only available method of proceeding is to reconstruct a second, supplementary list of ex-Nazis from Eutin, and then to compare their party numbers with those in the original list. If the numbers of these additional National Socialists, or at least most of them, also belong to the already established series, it could perhaps be concluded that any numbers still "missing" were given to Eutin members as well.

There are a number of sources available, including the essay by party historian Diercks on the "Struggle and Rise of the NSDAP in Eutin", National Socialist electoral petitions from the years 1928-32, and post-1945 lists of former "active Nazis" still residing in the town, which together provide a total of 99 names of additional Eutin Nazis. All of these were

60 Tyrell, for example, records that "the fluctuation was relatively heavy, several Gauleiters reported between 10 and 15\%" (Führer befiehl, p. 352). See also note 1. Following the re-founding of the NSDAP in 1925, membership numbers (with relatively few exceptions) were assigned in sequence as applications were received from the different Gau offices and processed by party headquarters. The numbers of those who quit or were ejected from the movement, however, were not given to new members, which resulted in a steadily increasing discrepancy between the nominal and the actual size of the party. Cf. Orlow, History of the Nazi Party, pp. 79, 110-11.

61 Kater, “Zur Soziographie”, p. 127. 
searched through the holdings of the BDC. Two who were not identified were both early leaders of the Ortsgruppe. Among those who could be, three emigrated to Canada in April 1930, several students left Eutin after completing their education, and a number were ejected from or quit the party for reasons unknown. ${ }^{62}$

The highest proportional rate of fluctuation in Eutin Nazi membership took place among four occupational categories: workers (22\% of the exmembers of the Ortsgruppe, compared with $14.5 \%$ in May 1932), ${ }^{63}$ civil servants $(6 \%$ versus $2.9 \%)$, and especially students (10\% versus $1.9 \%)$ and farmers $(7.4 \%$ versus $1.3 \%)$. Whereas merchants and businessmen left the Ortsgruppe in approximately the same proportion as they were still represented in it by May 1932, white-collar employees, handicraftsmen, professionals and unemployed women were the most "loyal" adherents of the party. The relative strength of each occupation represented in the total known membership of the Ortsgruppe prior to 30 January 1933 is not significantly different than that shown in Table 1, except in the case of farmers (13 out of 568 combined members, $2.3 \%$ instead of $1.3 \%$ ) and students ( 19 or $3.3 \%$ versus $1.9 \%$ ).

An examination of the party numbers of the 99 additional Nazis reveals that 52 of them fall within one or the other of the 55 series of numbers derived from Table 5. Another 23 numbers either immediately precede or follow such a series; while 13 more fall so close that they evidently represent a further extension of various series. Only 11 numbers are completely unrelated to any in Table 5 (although two pairs of these constitute new series and another are separated by just a single number). Before drawing any conclusions from these observations, however, two additional facts should be noted. In the first place, all of the 390 Eutin Nazis whose party numbers fall within a series in Table 5 originally joined the Ortsgruppe in the town. Secondly, among a control group of some 80 functionaries and members who entered the NSDAP before December

62 Diercks, "Kampf und Aufstieg", pp. 49f.; LASH, Regierung Eutin, A IV 4 and 10, "Provinzialrat (Landesausschuss)-Wahlen" and "Deutscher Reichstag-Wahlen"; and SAE, No 2502, Nationalsozialistische Deutsche Arbeiterpartei (NSDAP) 1933-1947, and No 2547, Entnazifizierung von Verwaltung und Wirtschaft 1945-1953. Cf. also correspondence between the Gauleitung Schleswig-Holstein and the Geschäftsstelle der NSDAP, Munich, 3 August, 1 and 3 December 1925, and reports from the former to the latter, 3 March, 18 May and 30 June 1927, and 25 August 1928, Bundesarchiv Koblenz, Sammlung Schumacher, 208 1, Vol. 2.

63 Workers may have been the chief victims of the local practice of excluding unemployed members unable to pay dues, to which Gau headquarters took strong but apparently futile exception. Cf. correspondence between ${ }^{-1}$ the Geschäftsstelle Eutin and NSDAP Gau Schleswig-Holstein, 15, 22 and 27 April 1931, USNA, T-81. roll 175, frs $317877 \mathrm{ff}$. 
1932 but in another unit than Eutin (except for about a dozen leaders of Ortsgruppen elsewhere in Landesteil Lübeck, almost all of them subsequently belonged to the party in the town), none had a number which fell within any of the series in Table 5. Even those who first became Nazis in another Ortsgruppe belonging to Gau Schleswig-Holstein (only 14 came from further afield) received numbers from Munich party headquarters which in no case were consecutive with any known numbers assigned to members from Eutin. ${ }^{64}$

Although none of this evidence is in itself or even taken together conclusive, nevertheless it appears reasonably certain that all of the "missing" numbers from the series in Table 5 were those of Eutin Nazis. That means that a great many more residents joined the Ortsgruppe in the town (even if they only belonged to it briefly) than are included in the May 1932 list - to say nothing of those others who joined the NSDAP elsewhere, spent some time in Eutin, and then moved away before the list was compiled. If the latter category of "transients" is probably beyond calculation, the number of Eutiner who either first became members there or were Nazis on the day Hitler was named Chancellor may well have totalled as many as $686 .{ }^{65}$ The turnover rate in the Ortsgruppe was therefore quite high: over 45\%. A considerable element of fluctuation was naturally caused by Nazis moving from one Ortsgruppe to another rather than either quitting or being excluded from the party. But if the randomly assembled group of additional members is representative of Eutin's experience (about three times as many of these left or were dropped from the NSDAP than merely changed their Ortsgruppe), then the local party underwent an actual rate of fluctuation of 34\%; that is, between 2.3 and 3.4 times greater than that estimated by various Gauleiter. Around 15\% of the town's voters between 1930 and 1932 at one point or another had likely been Nazis; over $10 \%$ still were in May

64 The nearest was only two numbers removed (it belonged to the leader of a neighbouring Ortsgruppe), and at least six others were within a hundred of the closest Eutin number. This proximity is not surprising, though, since headquarters received applications from the different $\mathrm{Gau}$ business offices and thereupon distributed new party numbers en bloc according to Gau membership (interview with Professor Dietrich Orlow, Hamburg, 21 January 1975). The question is: did an individual Ortsgruppe also receive a closed block of numbers? It appears from the Eutin example that they indeed did.

65 That is: 412 from Table 5; plus the 310 "missing numbers", minus both the 52 newly identified Eutin Nazis among these and also the 54 from the original list for whom party numbers could not be found (on the conservative assumption that all of these held numbers among those "missing"): plus the 49 other new Eutin numbers discovered; plus, finally, 21 additional "missing numbers" from extended or new series derived from those same numbers. 
$1932 .{ }^{66}$ Whether the development of the Eutin Ortsgruppe in these respects, as in others, differed significantly from that elsewhere, or on the contrary was fairly typical, must await further examination of the NSDAP at the "grass-roots" level.

${ }^{66}$ By comparison, the closest large city, Lübeck, counted 1,170 party members among its population of 130,000 (that is, $11 \%$ ) in March 1932. Der NSDAP K reis Lübeck, op. cit., p. 87. However, there were only about 1,000 National Socialists in a second Hanseatic city-state, Bremen, with over a half-million inhabitants when Hitler came to power. Herbert Schwarzwälder, Die Machtergreifung der NSDAP in Bremen 1933 (Bremen, 1966), p. 9. 